Regional Review

\title{
Hepatitis $B$ and $C$ virus infections among pregnant women in Arab and African countries
}

\author{
Gasim I. Gasim¹, Intisar A. Murad², Ishag Adam² \\ ${ }^{1}$ College of Medicine, Qassim University, City, Saudi Arabia \\ ${ }^{2}$ Faculty of Medicine, Khartoum University, City, Sudan
}

\begin{abstract}
Introduction: The epidemiology of viral hepatitis during pregnancy is of paramount importance for health planners and program managers. Data on viral hepatitis during pregnancy are not readily available in many African and Arab countries. Both regions have their own unique geography, and comprise over 59 states with crossover and interaction of different cultures.

Methodology: A systematic electronic search of the published literature was conducted and data on epidemiology and risk factors of maternal hepatitis B virus (HBV) infection and hepatitis $\mathrm{C}(\mathrm{HCV})$ infection in Arab and African countries were extracted from relevant studies.

Results: The serology of hepatitis viruses varies greatly among these countries, with different viral genotype patterns. Such a variation in prevalence could be explained by the different risk factors involved. Sexual contact, perinatal infection, blood and its derivatives, hemodialysis, intravenous and percutaneous drug use, and occupational, habitual, and social behavior have been identified as risk factors for hepatitis transmission in various settings in these countries.

Conclusions: Infection from hepatitis $\mathrm{B}$ and $\mathrm{C}$ viruses imposes major socioeconomic and even political burdens on such young and dynamic societies. Thus strategies and clear policies of intervention are required to combat the consequences of hepatitis $\mathrm{B}$ and $\mathrm{C}$ at both the regional and national levels.
\end{abstract}

Key words: hepatitis B; hepatitis C; epidemiology; Africa; Arab; Middle East; hepatitis B serology; hepatitis C serology

J Infect Dev Ctries 2013; 7(8):566-578. doi:10.3855/jidc.3243

(Received 22 December 2012 - Accepted 05 May 2013)

Copyright (C) 2013 Gasim et al. This is an open-access article distributed under the Creative Commons Attribution License, which permits unrestricted use, distribution, and reproduction in any medium, provided the original work is properly cited.

\section{Introduction}

Hepatitis B virus (HBV) is a member of the Hepadnaviridae family; it is a DNA virus with partially double-stranded DNA and a core antigen surrounded by a shell containing hepatitis B surface antigen (HBsAg) [1]. HBV has numerous antigenic components such as HBsAg, hepatitis B core antigen ( $\mathrm{HBcAg})$, and hepatitis $\mathrm{B}$ e antigen ( $\mathrm{HBeAg})$. The HBV genome harbors 3200 nucleotides and it can encode four groups of proteins and their regulatory components by shifting the reading frames over the same genetic matter [2]. Immunity against $\mathrm{HBV}$ infection is via a response to $\mathrm{HBcAg}$ and $\mathrm{HBsAg}$. Antibodies to $\mathrm{HBcAg}$ (anti-HBc) are indicative of infection: IgM anti-HBc signifies recent infection and usually disappears within six months, whereas $\mathrm{IgG}$ anti-HBc persists for life and indicates past infection. The presence of antibody against HBsAg (anti-HBs) appears after clearance of HBsAg or after immunization. $\mathrm{HBsAg}$ persisting for a period exceeding six months is defined as chronic HBV infection [3].
Despite availability of a vaccine and antiviral treatment, HBV infection is still a major health problem causing considerable morbidity and mortality [4-6]. The World Health Organization (WHO) estimates the burden of HBV infection to be approximately 2 billion, $>350$ million chronically infected with $\mathrm{HBV}$, and 500,000-700,000 patients die annually as a result of HBV-related liver disease, such as liver cirrhosis, end-stage liver disease, or hepatocellular carcinoma, with most of these deaths in developing countries $[7,8]$.

Hepatitis $\mathrm{C}$ virus (HCV) infection is another major worldwide public health concern. The WHO estimates that around 3\% of the world's population has chronic $\mathrm{HCV}$ infection, with more than one million new cases annually, the majority of which occurring in Africa $[9,10]$. Direct percutaneous inoculation is the most efficient mode of transmission of $\mathrm{HCV}$, but sexual, household, occupational, and vertical transmission may also be important [11].

Viral hepatitis during pregnancy is closely related to high risks of maternal complications including 
premature contractions, placenta praevia, preterm delivery, placental separation, premature rupture of membranes, vaginal bleeding, preterm labor, gestational diabetes mellitus and mortality [12-15], with a high rate of vertical transmission leading to fetal and neonatal hepatitis [12-15]. The epidemiological data for these viruses might be essential to program managers, health planners, and relevant for helping to develop vaccine and screening packages in antenatal care clinics.

It is also important to consider the weaknesses of regional studies in African and Arab countries, where most of the epidemiological investigations are performed on individuals based upon studying the seroprevalence of $\mathrm{HBV}$ and $\mathrm{HCV}$ among specific groups such as blood donors, health-care employees, or patients undergoing hemodialysis. Thus the current review aims to investigate the prevalence and possible risk factors for $\mathrm{HBV}$ and $\mathrm{HCV}$ infection among pregnant women in African and Arab countries.

\section{Methodology}

A systematic electronic search of the published literature was conducted and data on the epidemiology and risk factors for maternal $\mathrm{HBV}$ and $\mathrm{HCV}$ infection in Arab and African countries were extracted from relevant studies. The databases were searched with the words "Hepatitis B virus", "Hepatitis C virus", "Arab", "Africa" and "pregnancy" used interchangeably in MEDLINE, Pubmed, MiPc library and Google, and sometimes also including names of particular countries.

\section{Epidemiology of HBV and HCV among pregnant women in Arab countries}

The Arab world is made up of heterogeneous states with variable levels of development and different approaches of concepts and priorities in health care. Basic health service facilities vary among these countries, with some successfully adopting modern methods of infection control, while others fail to incorporate such recommendations [16]. Failure to implement international standards is the rule in the institutions and health services in most Arab countries. This failure can be attributed to a group of factors including the bureaucracy and hierarchy among their health systems and education, lack of knowledge, and lack of basic skills $[16,17]$. HBV and HCV infections are a persistent issue in the entire Arab world, where the average prevalence rate of $\mathrm{HBV}$ infection ranges from $2 \%$ to more than $8 \% \quad[18,19]$, while the prevalence of HCV ranges between $0.4-23 \%$ [19]. Prevalence shows great variability from one region to another, and even among countries of the same region.

HBV and HCV during pregnancy have a high vertical transmission rate, causing fetal and neonatal hepatitis and maternal mortality [20]. Neonatal hepatitis can lead to chronic virus carriage, which in turn may lead to liver cirrhosis and hepatocellular carcinoma in young adults $[21,22]$. Acute HBV carries a particular risk, not only for the mother, but also for the newborn. Acute HCV during pregnancy is not commonly seen, and its transmission rate is low [21,22] (Tables 1 and 2; Figures 1 and 2).

Table 1. Prevalence and genotypes of HBV among pregnant women in Arab countries

\begin{tabular}{|c|c|c|c|c|}
\hline Region /country & Prevalence of $\mathrm{HBV} \%$ & Reference & Predominant genotype & Reference \\
\hline Saudi Arabia & 1.6 & 21 & $\mathrm{D}$ & 39 \\
\hline Oman & 7.1 & 24 & $\mathrm{D}$ & 36 \\
\hline Qatar & 1 & 24 & $\mathrm{D}$ & 36 \\
\hline UAE & 1.5 & 24 & $\mathrm{D}$ & 40 \\
\hline Yemen & 10.8 & 23 & $\mathrm{D}$ & 36 \\
\hline Lebanon & 2.9 & 25 & $\mathrm{D}$ & 42 \\
\hline Jordan & 4.3 & 26 & $\mathrm{D}$ & 43 \\
\hline Sudan & 5.6 & 29 & $\mathrm{D}$ and $\mathrm{E}$ & 30 \\
\hline Egypt & 4.0 & 28 & $\mathrm{D}$ & 31 \\
\hline Libya & 1.5 & 32 & $\mathrm{D}$ & 44 \\
\hline Algeria & 1.6 & 55 & $\mathrm{D}$ & 45 \\
\hline Tunisia & 4.0 & 35 & $\mathrm{D}$ & 35 \\
\hline Mauritania & 10.7 & 39 & $\mathrm{D}$ & 39 \\
\hline
\end{tabular}


Table 2. Prevalence and genotypes of HBV among pregnant women in African countries

\begin{tabular}{lllll}
\hline Region /country & Prevalence of HBV\% & Reference & Genotype & Reference \\
\hline Tanzania & 6.3 & 69 & $\mathrm{~A}$ & 118 \\
Uganda & 4.9 & 78 & $\mathrm{~A}$ & 122 \\
Rwanda & 2.4 & 78 & $\mathrm{~A}$ & 121 \\
Malawi & 13 & 66 & $\mathrm{~A}$ & 122 \\
Zambia & 6.5 & 65 & $\mathrm{~A}$ & 122 \\
Zimbabwe & 3.3 & 64 & $\mathrm{~A}$ & 122 \\
Nigeria & $6.08-12.5$ & 89,99 & $\mathrm{E}$ & 122 \\
Cameroon & 7.85 & 74 & $\mathrm{E}$ & 122 \\
Ghana & 16 & 76 & $\mathrm{E}$ & 122 \\
Burkina Faso & 9.8 & 79 & $\mathrm{E}$ & 122 \\
South Africa & 4.6 & 70 & $\mathrm{~A}$ & 122 \\
Congo-Brazzaville & 6.5 & 73 & $\mathrm{E}$ & 122 \\
Sierra Leone & 6.2 & 77 & $\mathrm{~A}$ & 122 \\
Mali & 8 & 80 & $\mathrm{E}$ & 122 \\
Ivory Coast & 8 & 81 & $\mathrm{E}$ & \\
\hline
\end{tabular}

Figure 1. Prevalence of $\mathrm{HBV}$ among pregnant women in Arab and African countries
Figure 2. Prevalence of $\mathrm{HCV}$ among pregnant women in Arab and African countries

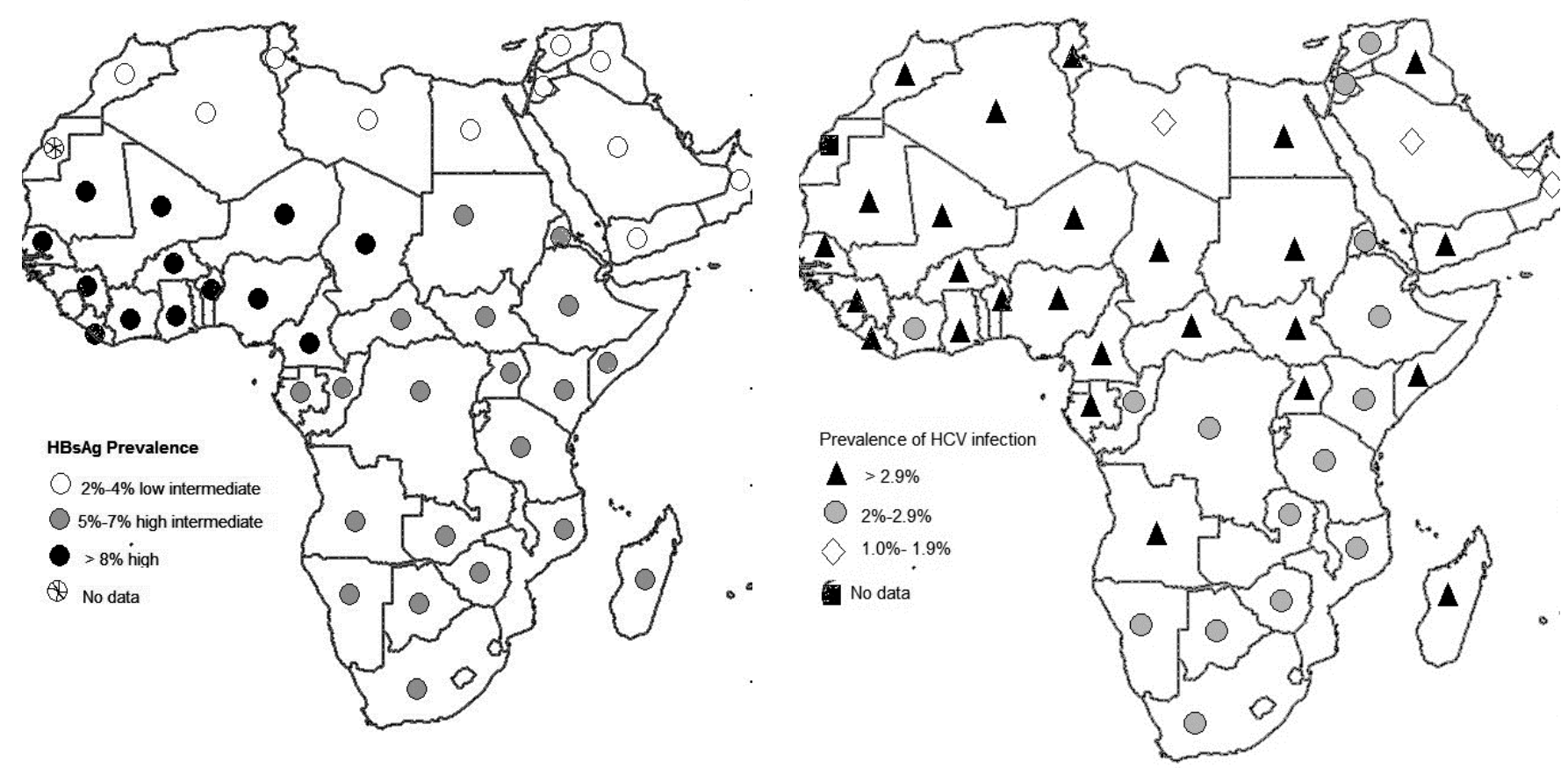


$H B V$ among pregnant women in the Arabian Peninsula region

The Arabian Peninsula comprises Saudi Arabia, Yemen, Oman, Qatar, Bahrain, the United Arab Emirates, and Kuwait. It is a unique and distinct geographical area comprising about $35 \%$ of the Arab world, and its coastal areas are the world's largest single source of crude oil. The prevalence of $\mathrm{HBV}$ among pregnant women in this region ranges from $1 \%$ to $7.1 \%$, which is considered a low to intermediate range in worldwide terms [23-26]. There have been few studies (with the exception of Saudi Arabia) of HBV among pregnant women in this area.

\section{$H B V$ among pregnant women in Bilad ash-Sham}

Bilad ash-Sham region of the Arab world comprises Syria, Lebanon, Jordan, and Palestine. Iraq is usually not included in this historical region; however, it will be included in this group for the purpose of this manuscript. Different studies have been performed in this region, where the prevalence of HBV among pregnant women is $2.9 \%$ to $4.3 \%$ [26,27].

$H B V$ among pregnant women in the Arabian Nile River region

Sudan and Egypt are the two countries in the Arabian Nile River region. HBV is extensively studied in Egypt, where appreciable efforts have been made in this setting [28]. Although there is a high prevalence of HBV $(6.7 \%)$ among the general population in Egypt [28], the prevalence among pregnant women is only $4 \%$ [29]. The prevalence of HBV among pregnant Sudanese women $(5.6 \%)$ is comparable to the prevalence in Egyptian women [30].

Therefore, the prevalence of HBV in the River Nile region is in the intermediate endemic range, with
Egypt being at the lower end of the spectrum and Sudan at the upper end. Genotype D is predominant although other genotypes are seen $[31,32]$.

$H B V$ among pregnant women in North African (Maghreb) region

The Maghreb region comprises Libya, Tunisia, Algeria, the Kingdom of Morocco, and Mauritania. The prevalence of $\mathrm{HBV}$ and its genotypes varies among the different populations of the Maghreb countries. It is least prevalent in Libya (1.5\%), followed by Algeria (1.6\%) and Tunisia (4\%), while it was $10 \%$ among pregnant women in Mauritania. Therefore, further studies are needed to determine the prevalence of HBV among the general population. The small number of subjects included in the studies we referred to might explain this variation; thus, larger more detailed studies are needed to gather reliable data [33-36].

\section{Genotypes}

$\mathrm{D}$ is the most common genotype among the different settings throughout the previously mentioned Arab states [37-46].

HCV among pregnant women in the Arabian Peninsula region

$\mathrm{HCV}$ prevalence varies greatly among prosperous and poor states in the Arabian Peninsula (Table 3; Figure 2). For example, it is reported to be $0.7 \%$ and $8.5 \%$ among Saudi and Yemeni pregnant women, respectively $[24,47]$. It is evident that in the lessdeveloped countries, there is a need for detailed studies on HCV, because the magnitude of the HCV problem is not well documented. Furthermore, lack of knowledge about the impact of foreign workers on the

Table 3. Prevalence and genotypes of HCV among pregnant women in Arab countries

\begin{tabular}{lllll}
\hline Region/country & Prevalence of HCV\% & Reference & $\begin{array}{l}\text { Predominant } \\
\text { genotype }\end{array}$ & Reference \\
\hline Saudi Arabia & 0.7 & 46 & 4 & 18 \\
Yemen & 8.5 & 23 & 4 & 18 \\
Iraq & 3.21 & 47 & 4 & 18 \\
Sudan & 0.6 & 29 & 4 & 18 \\
Egypt & 8.6 & 49 & 4 & 18 \\
Libya & 0.36 & 53 & 4 & 18 \\
Tunisia & 0.5 & 54 & 4 & 18 \\
Algeria & 2.5 & 55 & 4 & 18 \\
Morocco & 1 & 58 & $1 \mathrm{~b}$ & 18 \\
\hline
\end{tabular}


prevalence of $\mathrm{HCV}$ is clouding the picture, particularly as a considerable number of these workers come from regions where $\mathrm{HCV}$ is considered to be endemic.

\section{HCV among pregnant women in Bilad ash-Sham} region

While there is lack of data on HCV infection among pregnant women in Bilad ash-Sham region, a prevalence of $3.21 \%$ was observed in Iraq [48]. The scarcity of data on HCV among pregnant women might reflect a lack of appreciation of the magnitude of the problem in this region.

\section{HCV among pregnant women in the Arabian Nile River region}

Considerable effort to investigate the epidemiology of $\mathrm{HCV}$ is undertaken in Egypt, which has a high prevalence of HCV among pregnant women $(8.6 \%)[23,49,50]$. In Sudan, the prevalence of HCV among pregnant women $(0.6 \%)$ is lower than that in the general population $(2.2 \%$ to $3 \%)$ [30,51,52]. Therefore, the northern part of the River Nile region is considered to be a highly endemic area for HCV and the southern part is less endemic, with a very low prevalence among pregnant women. Genotype 4 is the predominant $(90 \%)$ genotype among the Egyptians [53] (Table 2; Figure 2).

\section{HCV among pregnant women in North African (Maghreb) region}

The epidemiology of HCV among pregnant women in the Maghreb region varies from one country to another. It is least prevalent in Libya, followed by Tunisia, the Kingdom of Morocco, Algeria, and Mauritania [54-57] (Table 3). HCV genotype 4 is the most prevalent among Libyans, while genotype 1 is more common in the rest of the Maghreb countries [58-61]. It is difficult to explain this variation, because there is much interaction between the people in these countries, and it is sometimes difficult to differentiate between them, apart from one aspect that might provide an explanation; namely, interaction with European communities in the later Maghreb countries, where there are more open communities than in Libya. Differences in reported prevalence could also be due to the type of study conducted; i.e., whether was a cross-sectional study, survey, or other type. Moreover, proximity to countries where a particular genotype is predominant can further explain the genotype situation in Libya where type 4 is more prevalent towards the eastern borders while type 1 predominates in the western regions [62].

\section{Epidemiology of HBV and HCV among pregnant women in African countries}

Heterogeneity in religion, culture and practices, and high HIV burden in sub-Saharan Africa are factors that might influence the epidemiology of HBV and HCV. For the purpose of simplification, we have divided Africa into five different geographical regions: the northern, eastern, southern, central and western regions. The northern region is entirely occupied by the Arab states and the status of $\mathrm{HCV}$ and $\mathrm{HBV}$ infection has already been described. Most of the countries in the other four regions suffer from political conflicts, drought, and famine, leading to large numbers of internally and externally displaced people, which might increase the prevalence of sexually transmitted diseases $[63,64]$ (Tables 2 and 4).

\section{HBV among pregnant women in Africa}

\section{Eastern region}

The eastern region of Africa comprises: (1) Tanzania, Kenya, Uganda, Rwanda, and Burundi, which are form the area around the great African lakes; an area where major conflicts have taken place in the past decade; (2) Djibouti, Eritrea, Ethiopia, and Somalia, which are collectively known as the Horn of Africa; (3) Mozambique and Madagascar, which are often considered part of Southern Africa; (4) Malawi, Zambia, and Zimbabwe (formerly the Central African Federation), which are also often included in Southern Africa; and (5) Comoros, Mauritius, and the Seychelles, which are small island nations in the Indian Ocean, along with Réunion and Mayotte, which are French overseas territories also in the Indian Ocean. This region is characterized by being one of the most politically unstable areas, where conflicts tend not to cease. HBV prevalence among pregnant women in the region mimics the epidemiology among the general population, and most countries fall in the moderate endemic zone apart from Somalia, where a high prevalence (37\%) was reported in 1987 [65-71]. Therefore it is clear that there is lack of information in this area.

\section{Southern region}

This southern region of Africa comprises Angola, Botswana, Lesotho, Namibia, South Africa, and Swaziland. With exception of South Africa, which has a high prevalence (4.6\%) [71], published studies on HBV in pregnancy are scarce in this group of countries. This area lies in the zone of moderate endemic when considering the general population with an estimated prevalence between $2 \%$ and $2.9 \%$ [72]. 
Table 4. Prevalence and genotypes of HCV among pregnant women in African countries

\begin{tabular}{|c|c|c|c|c|}
\hline Region /country & $\begin{array}{l}\text { Prevalence of } \\
\text { HCV\% }\end{array}$ & Reference & Predominant genotype & Reference \\
\hline Tanzania & 5 & 69 & 4 & 117 \\
\hline Kenya & $?$ & & 1a & 118 \\
\hline Uganda & 2 & 78 & $\mathrm{~N} / \mathrm{A}$ & \\
\hline Rwanda & 4.9 & 78 & N/A & \\
\hline Burundi & $?$ & & 4 & 128 \\
\hline Ethiopia & $?$ & & $1,2,3,4,5$ & 129 \\
\hline Somalia & $?$ & & $3 \mathrm{H}$ & 130 \\
\hline Mozambique & $?$ & & $1 \mathrm{a}, 2 \mathrm{a}, 4$ and $5 \mathrm{a}$ & 132 \\
\hline Madagascar & $?$ & & $1 b, 2$ & 131 \\
\hline Malawi & 16.5 & 66 & N/A & \\
\hline Nigeria & 9.2 & 111 & 2 & 128 \\
\hline Cameroon & $?$ & & 4 & 123 \\
\hline South Africa & $?$ & & 5,6 & 124 \\
\hline Democratic Republic of the Congo & 6.6 & 88 & 4 & 123 \\
\hline Ivory Coast & 1 & 81 & 2 & 128 \\
\hline Equatorial Guinea, São Tomé and Príncipe & $?$ & & 4 & 123 \\
\hline Gabon & 2. & 90 & 4 & 123 \\
\hline
\end{tabular}

\section{Central region}

The central region is composed of Cameroon, Central African Republic, Republic of Chad, Republic of Congo, Democratic Republic of Congo, Equatorial Guinea, Gabonese Republic, and São Tomé and Príncipe. HBV prevalence among pregnant women varies from one country to another, and mostly ranges between $6 \%$ and $9.5 \%$ [73-75].

\section{Western region}

The western region comprises Benin, Burkina Faso, Cape Verde, Ivory Coast, and Republic of Gambia, Republic of Ghana, Guinea-Bissau, Republic of Liberia, Mali, Niger, Federal Republic of Nigeria, Senegal, Sierra Leone, Togo, and the Canary Islands. $\mathrm{HBV}$ prevalence among pregnant women is high in this region and varies between $6.2 \%$ and $16 \%$ with preponderance toward the upper end [76-82].

\section{HCV among pregnant women in Africa}

\section{Eastern region}

Studies of HCV prevalence in the eastern region of Africa have been scarce and controversial, with some reports showing the prevalence to be in the high to intermediate range $(2-2.9 \%)$ [72], while others show it in the very low range $(0 \%$ to $2 \%)$ [83]; this discrepancy could be explained by the use of more specific tests and investigating a healthy population in the latter study.

\section{Southern region}

$\mathrm{HCV}$ prevalence in the southern region of Africa has not been well studied, but estimates put the region in the intermediate group in terms of endemic [72]. Another important feature of this part of Africa is the high prevalence of HIV infection, especially among pregnant women, with prevalence rates approaching $28 \%$ [84,85]. Nevertheless, the prevalence of coinfection was low $(0.001 \%-0.1 \%) \quad[86,87]$. The scarcity of published data makes clear the need for more studies in this region.

\section{Central region}

The central region of Africa is considered to be one of the most heavily infected parts in the world, with prevalence rates approaching more than $13 \%$ of the general population in some areas [88]. Cameroon has the highest prevalence $(13.8 \%)$, followed by Burundi (11.3\%) and Gabon (9.2\%) [88]. Prevalence in this region has reached $4.3 \%$ among pregnant women [89-91]. The risk factors involved were mainly infected blood and its products (likely in the past), intravenous drug abuse, transfusion of untested blood, unsterile medical and dental procedures, and the use of traditional procedures where blood exposure is 
involved [88]. Despite being an area of high prevalence for HCV, studies have been scarce, which could be explained by lack of resources.

\section{Western region}

$\mathrm{HCV}$ in the western region of Africa is considered to be highly endemic, and the prevalence among pregnant women is 3\% in Nigeria [92] and $2.2 \%$ in Burkina Faso [93]. Different studies classified this region among the high endemic regions [72].

\section{Factors associated with transmission of HBV and HCV among pregnant women in Africa and Arab countries}

The epidemiology of $\mathrm{HBV}$ and $\mathrm{HCV}$ among pregnant women in African and Arab countries does not differ greatly from that in other developing countries, apart from some particular factors in the Arab countries, where the influence and intermingling of religious and cultural influences might play an important role. A variety of risk factors have been found to be associated with high prevalence rates for both $\mathrm{HBV}$ and $\mathrm{HCV}$; however, the emphasis on these risk factors varies greatly from one country to another.

\section{Factors associated with transmission of HBV among pregnant women in Africa and Arab countries \\ Blood and blood products}

HBV is a blood-borne virus. The main routes of HBV transmission are the sexual and parenteral routes [94]. Blood and its products remain major causes of HBV transmission in Arab countries; most of which fail to fulfill the criteria of a modern, safe blood transfusion system. However, there is a great controversy in studies conducted in different Arab countries concerning the impact of blood transfusion on the status of HBV infection. Studies from Egypt have reported that HBV infection was found to be associated with blood transfusion among pregnant women along with the finding that it is also associated with HBV infection in patients with chronic hematological disorders requiring frequent blood transfusions [29,95]. Several other studies have reported higher prevalence among those dependent on blood and blood products, especially when compared with reports of a decline in seroprevalence [96-101]. In contrast to the above-mentioned findings, studies of HBV infection in pregnant women in Sudan, Yemen, and Mauritania have failed to show any evidence of blood transfusion being a risk factor for virus transmission [24,30,39]. This difference might be explained by better safety precautions being taken for blood donation, where screening for the virus is regularly undertaken. The available current data indicate that screening for HBV markers is mandatory today in all blood banks throughout Arab countries, although in some clinics patients might be required to pay for such tests.

\section{Circumcision}

Female circumcision, although legally condemned by several Arab governments, is performed at home by midwives or health workers on young women, and might well be a source of infection in women. It is a risk factor for HBV infection in Yemen [24], but this observation contradicts the findings of some other studies in Arab and African countries, for example among pregnant Sudanese and Nigerian women $[30,100]$. This discrepancy might be explained by the difference in hygiene and aseptic precautions regarding materials used in the procedures among the different countries.

\section{Sociodemographic factors}

Sociodemographic factors such as age, education level, and gravidity have been found not to be significant factors associated with transmission of HBV [24,30,39,100,101]; however, some reports have stated that becoming sexually active at an early age is a risk factor as has been found by Rabiu et al. among Nigerian pregnant women [100]. Other important sociodemographic risk factors for HBV infection that cannot be ignored are history of intravenous drug abuse, imprisonment, and history of multiple partners. These risk factors have not been studied, likely because of the religious and cultural backgrounds of such communities.

\section{Medical or surgical risk factors}

Medical and surgical risk factors such as surgical procedures, home delivery, dental procedures, and history of jaundice were all found not to be significant $[24,30,39,100,101]$.

\section{Factors associated with transmission of HCV among pregnant women in Africa and Arabian countries}

Blood and blood products

Before 1992, blood transfusion was one of the major risk factors for $\mathrm{HCV}$ transmission, but the risk has declined since the start of screening for $\mathrm{HCV}$ in 2001. Risk of HCV infection from a single unit of transfused blood has declined to less than one per 
million transfused units [102]. However, the risk of $\mathrm{HCV}$ transmission through blood still exists in some developing countries because of failure to adequately screen donors due to financial constraints $[29,103]$. However, most studies have found that blood transfusion is no longer a risk factor for $\mathrm{HCV}$ in pregnancy $[50,104]$, and the same is generally true in Arab countries [24], although some Arab countries have found it to be a risk factor [50]. In contrast, blood transfusion might well be a risk factor among African countries, such as Ghana and Kenya, and probably a number of others, because of budget shortfalls $[105,106,107]$.

\section{Sociodemographic factors}

Sociodemographic factors in $\mathrm{HCV}$ transmission have shown great variation among studies, depending on the factor itself. Some researchers have found that increasing age is a risk factor, which might be explained by the cumulative effect phenomena, probably attributed to the use of unsterile injections and other instruments used in traditional scarification and tattooing [10,50], but others have found no association [24]. Although specific data on age are scarce, the literature shows some variations in different geographical regions throughout the world [50]. Some researchers have found an association with low parity [24], whereas others have found no such relation [50]. Another sociodemographic factor of concern is educational level. It has been found that women who have received less than secondary school level education are at higher risk [24], and an Egyptian group has found that a low level of maternal education is a risk factor for HCV infection of children [106]. Being the long-term steady sex partner of an HCVinfected individual is not a risk factor [108], as the role of sexual transmission itself in HCV infection needs validation [109]. An important but controversial risk factor is intrafamilial exposure [52,95,100, 110]. In Iraq, repeated abortion has been shown to be a risk factor [48], probably because of the possibility of curettage and blood transfusion. Other important sociodemographic factors, such as intravenous drug abuse and multiple sexual partners, have not been investigated, probably because of hindrance by the cultural background.

\section{Mother-to-infant transmission}

Vertical transmission from mothers to infants is definite in HBV infection. However, this mode of transmission awaits confirmation for $\mathrm{HCV}$, although some studies have assumed this possibility. One such investigation detected antibodies to $\mathrm{HCV}$ in the umbilical cord while another studied various viral parameters among two of the babies born to Hepatitis $\mathrm{C}$ positive mothers and concluded that vertical transmission is seen among $\mathrm{HCV}$ infected pregnant mothers without the presence of human immune deficiency virus $[111,112]$.

\section{Tattoos, scarification, and tribal marks}

Tattoos, scarification, and tribal marks are widespread practices in Africa, and have been linked to $\mathrm{HCV}$ transmission by some researchers [113].

\section{Strategies and preventive measures to control HBV and HCV infection among pregnant women in Arab and African countries}

The status of HBV and HCV in pregnant women in Arab and African countries is a persistent issue for all sectors involved in public health, in particular, those that are involved in health strategic planning. There is great variation among African and Arab countries concerning the prevalence of $\mathrm{HBV}$ and $\mathrm{HCV}$ and other problematic issues, which should be taken into consideration regarding the prevention of $\mathrm{HBV}$ and $\mathrm{HCV}$ in each country. Major measures to be implemented are to encompass immediate primary intervention strategies and long-term prevention plans. Such targeted prevention strategies have reduced transmission of $\mathrm{HBV}$ in developed countries, particularly among high-risk groups. Risk-reduction counseling and HBV screening programs should be directed at specific populations, as suggested by the Centers for Disease Control in the United States. Universal and specific infection control measures that are directed towards nosocomial infection and units or persons in hospitals and health-care centers that are rendered prone to $\mathrm{HBV}$ and $\mathrm{HCV}$ infection are necessary. Specific prevention programs should be implemented by adopting better and more efficient cleansing and standard sterilization practices to stop nosocomial and iatrogenic transmission of HBV and HCV. Risky patient care practices associated with higher $\mathrm{HBV}$ and $\mathrm{HCV}$ prevalence among pregnant women should be identified, and recommendations and appropriate precautions in these settings should be adopted.

Although blood transfusion was not strongly suspected in most of the studies conducted to date, advanced laboratory screening methods for blood and blood products should be central to any further programs, to further reduce or at least maintain the low number of transfusion-related transmissions. Once 
patients are discovered to have hepatitis B or C, they require counselling and proper clinical evaluation to eliminate the risk of transmission and halt the progression of the disease. Therefore, countries that lack such programs must adopt them.

\section{Vaccination}

Since the launch of the first universal hepatitis B vaccination program for infants in July 1984 in Taiwan, infant immunization programs in different countries have resulted in marked reductions in the incidence and prevalence of hepatitis B among younger members of these populations [114-117]. This has been marked in Arab countries such as Libya, where the prevalence among pregnant women dropped from $2.8 \%$ to $2.1 \%$ in three years from 2003 , and then to $1.5 \%$ in 2010 , which is likely owing to the effect of vaccination, which has been provided since 2000 [33]. The picture might be changing in the rest of the Arab states because of vaccination. Previous data shed light on the efficacy of hepatitis B vaccine among some of the Arab and African countries (reference is required), and on the need to adhere to and reinforce such programs to achieve full and lasting serological protection.

\section{Future challenges and conclusion}

$\mathrm{HBV}$ and HCV are serious growing problems in African and Arab countries, and they have great socioeconomic impact that might affect future generations and influence the infrastructure of such dynamic states. Despite their great economic and natural resources, unfortunately none of the countries studied has shown meticulous and clear national strategic or regional scientific plans to meet the future challenges that HBV and HCV may bring. Prevalence of $\mathrm{HBV}$ and $\mathrm{HCV}$ is destined to increase further among African and Arab countries, especially when considering the issue of vertical transmission, which should be an incentive for further measures. Hence there is a great need to conduct studies that will guide proper planning to deal with the health issues connected with HBV and HCV.

We conclude that there are many gaps in our knowledge about the prevalence of HBV and HCV in pregnant women in Arab and African countries that are waiting to be filled. Most of the previous studies have demonstrated a high prevalence of both HBV and $\mathrm{HCV}$, although most of these studies were small; therefore, larger studies are needed in most of these countries. Finally, it is noticeable that HBV prevalence in several countries is on the decline, reflecting the positive effect of immunization.

\section{References}

1. Seeger C, Mason WS (2000) Hepatitis B virus biology. Microbiol Mol Biol Rev 64: 51-68.

2. Chisari FV, Ferrari C, Mondelli MU (1989) Hepatitis B virus structure and biology. Microb Pathog 6: 311-325.

3. So Young Kwon, Chang Hong Lee. Epidemiology and prevention of hepatitis B virus infection. Korean J Hepatol. 2011 June; 17: 87-95.

4. Chaiba E, Coimbraa BGMM, Galva oa FHF, Tatebea ER,Shinzatoa MS,.D'Albuquerquea LAC and Massad E (2012) Does anti-hepatitis B virus vaccine make any difference in long-term number of liver transplantation? Clin Transplant: 26: E590-E595.

5. Gasim I. Gasim (2013) Hepatitis B in the Arab world: where do we stand? AJG: 14: 35-43.

6. Harkisoen S, Arends JE, van Erpecum KJ, van den Hoek A, Hoepelman AI (2012) Hepatitis B viral load and risk of HBVrelated liver disease: from East to West? Ann Hepatol 11: 164-171.

7. World Health Organization (2008) Hepatitis B. World Health Organization Fact Sheet 204 August. Available from:http://www.who.int/mediacentre/factsheet/fs204/en.

8. World Health Organization. Sixty third world health assembly 25(2011). World Health Organization March. Available from: http://apps.who.int/gb/ebwha/pdf files/WHA63/A63_15en.pdf.

9. World Health Organization (1999) Global surveillance and control of hepatitis C. Report of a WHO Consultation organized in collaboration with the Viral Hepatitis Prevention Board, Antwerp, Belgium. J Viral Hepat 6: 35-47.

10. Shepard CW, Finelli L, Alter MJ (2005) Global epidemiology of hepatitis C virus infection. Lancet Infect Dis 5: 558-567.

11. Memon MI, Memon MA M (2002): Hepatitis C an epidemiological review. J Viral Hepat 9: 84-100.

12. Elinav E, Ben-Dov IZ, Shapira Y, Daudi N, Adler R, Shouval D, Ackerman Z (2006) Acute hepatitis A infection in pregnancy is associated with high rates of gestational complications and preterm labor. Gastroenterology 130: 1129-1134.

13. Ornoy A, Tenenbaum A (2006) Pregnancy outcome following infections by coxsackie, echo, measles, mumps, hepatitis, polio and encephalitis viruses. Reprod Toxicol 21:446-457.

14. Tse KY, Ho LF, Lao T (2005) The impact of maternal HBsAg carrier status on pregnancy outcomes: a case-control study. J Hepatol 43: 771-775.

15. Lu Y, Chen Y, Xiao X, Liang X, Li J, Huang S, Chen X, Hocher B (2012) [Impact of maternal hepatitis B surface antigen carrier status on preterm delivery in southern China]. Nan Fang Yi Ke Da Xue Xue Bao 32:1369-1372.

16. Daw MA, Shawky S (2002) "Going beyond the curriculum to promote medical education and practice (multiple letters)," Saudi Med J 1: 116-117.

17. Daw M, Elkhammas E (2008) Libyan medical education; time to move forward. Libyan J Med 1: 1-3.

18. CDC, Yellow book (2011) Chapter 3, Infectious Diseases Related to Travel, Hepatitis B http://wwwnc.cdc.gov/travel/yellowbook/2010/chapter2/hepatitis-b.aspx Reviewed Jan. 
19. Daw MA, Dau AA (2012) Hepatitis C Virus in Arab World: A State of Concern. Scientific World Journal. Article ID 719494, 12 pages.

20. Ali AA and Adam I (2011) Lack of antenatal care, education, and high maternal mortality in Kassala hospital, eastern Sudan during 2005-2009. J Matern Fetal Neonatal Med 24:1077-1078.

21. Shukla S, Mehta G, Jais M, Singh A (2011) A Prospective Study on Acute Viral Hepatitis in Pregnancy; Seroprevalence, and Fetomaternal Outcome of 100 cases. J Biosci Tech 2: $279-286$

22. Sookoian S (2006) Liver disease during pregnancy: acute viral hepatitis. Ann Hepatol 5:231-6.

23. Alrowaily MA, Abolfotouh MA, Ferwanah MS (2008) Hepatitis B virus sero-prevalence among pregnant females in Saudi Arabia. Saudi J Gastroenterol 14: 70-72.

24. Murad EA, Babiker SM, Gasim GI, Rayis DA, Adam I (2013) Epidemiology of hepatitis $\mathrm{B}$ and hepatitis $\mathrm{C}$ virus infections in pregnant women in Sana'a, Yemen. BMC Pregnancy and Childbirth, 13: 127.

25. Al Awaidy S, Abu-Elyazeed R, Al Hosani H, Al Mulla A, Al Busaiedy S, Al Amiry A, Farah Z, Al Marrie A, Bock HL, AlShaar I, Shah S (2006) Sero-epidemiology of hepatitis B infection in pregnant women in Oman, Qatar and the United Arab Emirates. J Infect 52: 202-206.

26. Nabulsi MM, Khalil AM, Farah AE, Araj GF (1997) Prevalence of hepatitis B surface antigen in pregnant Lebanese women. Int J Gynaecol Obstet 58: 243-244.

27. Batayneh N, Bdour S (2002) Risk of perinatal transmission of hepatitis B virus in Jordan. Infect Dis Obstet Gynecol 10:127132.

28. Lehman EM, Wilson ML (2009) Epidemiology of hepatitis viruses among hepatocellular carcinoma cases and healthy people in Egypt: a systematic review and meta-analysis. Int $\mathbf{J}$ Cancer 124: 690-697.

29. Zahran KM, Badary MS, Agban MN, Abdel Aziz NH (2010) Pattern of hepatitis virus infection among pregnant women and their newborns at the Women's Health Center of Assiut University, Upper Egypt. Int J Gynaecol Obstet 111: 171174.

30. Elsheikh RM, Daak AA, Elsheikh MA, Karsany MS, Adam I (2007) Hepatitis B virus and hepatitis C virus in pregnant Sudanese women. Virol J 4: 104.

31. Mahgoub S, Candotti D, El Ekiaby M, Allain JP (2011) Hepatitis B Virus (HBV) Infection and Recombination between HBV Genotypes D and E in Asymptomatic Blood Donors from Khartoum, Sudan. J Clin Microbiol 49: 298-306.

32. Ragheb M, Elkady A, Tanaka Y, Murakami S, Attia FM, Hassan AA, Hassan MF, Shedid MM, Abdel Reheem HB, Khan A, Mizokami M (2012) Multiple intra-familial transmission patterns of hepatitis B virus genotype D in northeastern Egypt. J Med Virol 84: 587-595.

33. El-Magrahe H, Furarah AR, El-Figih K, El-Urshfany S, Ghenghesh KS (2010) Maternal and neonatal seroprevalence of Hepatitis B surface antigen (HBsAg) in Tripoli, Libya. J Infect Dev Ctries. 4: 168-170.

34. Halima SB, Bahri O, Maamouri N, Cheikh I, Alaya NB, Sadraoui A, Azaiez O, Azouz M, Mami NB, Triki H (2010) Serological and molecular expression of Hepatitis B infection in patients with chronic Hepatitis C from Tunisia, North Africa. Virol J 7: 229.

35. Hannachi N, Bahri O, Mhalla S, Marzouk M, Sadraoui A, Belguith A, Triki H, Boukadida J (2009) [Hepatitis B virus infection in Tunisian pregnant women: risk factors and viral DNA levels in HBe antigen negative women]. Pathol Biol (Paris). 57: e43-47.

36. Kamal SM, Mahmoud S, Hafez T, El-Fouly R (2010) Viral hepatitis A to E in South Mediterranean Countries. Medit J Hemat Infect Dis 2 e201000.

37. Allain JP (2006) Epidemiology of Hepatitis B virus and genotype. J Clin Virol 36. 1 S12-S17.

38. Kitab B, El Feydi AE, Afifi R, Derdabi O, Cherradi Y, Benazzouz M, Rebbani K, Brahim I, Salih Alj H, Zoulim F, Trepo C, Chemin I, Ezzikouri S, Benjelloun S (2011) Hepatitis B genotypes/subgenotypes and MHR variants among Moroccan chronic carriers. J Infect 63: 66-75.

39. Mansour W, Malick FZ, Sidiya A, Ishagh E, Chekaraou MA, Veillon P, Ducancelle A, Brichler S, Le Gal F, Lo B, Gordien E, Lunel-Fabiani F (2012) Prevalence, risk factors, and molecular epidemiology of hepatitis B and hepatitis delta virus in pregnant women and in patients in Mauritania. J Med Virol 84: 1186-1198.

40. Abdo AA, Al-Jarallah BM, Sanai FM, Hersi AS, Al-Swat K, Azzam NA, Al-Dukhayil M, Al-Maarik A, Al-Faleh FZ (2006) Hepatitis B genotypes: relation to clinical outcome in patients with chronic hepatitis B in Saudi Arabia. World J Gastroenterol 12: 7019-7024.

41. Alfaresi M, Elkoush A, Alshehhi H, Alzaabi A, Islam A (2010) Hepatitis B virus genotypes and precore and core mutants in UAE patients. Virol J 7: 160.

42. Antaki N, Haffar S, Ali Deeb S, Assaad F, Abou Harb R, Zeibane N, Nasserelddine M, Ibrahim N, Alhaj N, Jabbour E, Aaraj R, Antaki F, Kebbewar K; Syrian Working Group for the Study of Viral Hepatitis (2010) High prevalence of HBV genotype D in Syria and the clinical characteristics of hepatitis B e antigen-negative chronic hepatitis B. Epidemiol Infect 138: 40-44.

43. El Chaar M, El Jisr T, Allain JP (2012) Hepatitis B DNA splicing in Lebanese blood donors and genotype A-E strains: implications for HBV DNA quantification and infectivity. J Clin Microbiol 10: 01251-12

44. Masaadeh HA, Hayajneh WA, Alqudah EA (2008) Hepatitis $B$ virus genotypes and lamivudine resistance mutations in Jordan. World J Gastroenterol 14: 7231-7234.

45. Salem MA, Elnifro EM, Alshuwen F (2012) Molecular Analysis of Hepatitis B Virus Isolates in Libya: Predominant Circulation of Hepatitis B Virus Genotype D. Journal of GHR 1: 119-121.

46. Khelifa F, Thibault V (2009) Characteristics of hepatitis B viral strains in chronic carrier patients from North-East Algeria. Pathol Biol (Paris) 57: 107-113.

47. Shobokshi OA, Serebour FE, Al-Drees AZ, Mitwalli AH, Qahtani A, Skakni LI (2003) Hepatitis C virus seroprevalence rate among Saudis. Saudi Med J 2: S81-86.

48. Al-Kubaisy WA, Niazi AD, Kubba K (2002) History of miscarriage as a risk factor for hepatitis $\mathrm{C}$ virus infection in pregnant Iraqi women. East Mediterr Health J 8: 239-244.

49. Yahia M (2011) Global health: a uniquely Egyptian epidemic. Nature 474: S12-S13.

50. AbdulQawi K, Youssef A, Metwally MA, Ragih I, AbdulHamid M, Shaheen A (2010) Prospective study of prevalence and risk factors for hepatitis $\mathrm{C}$ in pregnant Egyptian women and its transmission to their infants. Croat Med J 51: 219-228.

51. Mudawi HM (2008) Epidemiology of viral hepatitis in Sudan. Clin Exp Gastroenterol 1: 9-13. 
52. Abou MA, Eltahir YM, Ali AS (2009) Seroprevalence of Hepatitis B virus and Hepatitis C virus among blood donors in Nyala, South Dar Fur, Sudan. Virol J 6: 146.

53. Kamal SM, Nasser IA (2008) Hepatitis C genotype 4: What we know and what we don't yet know. Hepatology 47: 13711383.

54. Mesi A, Abudher A, El-Gadi S (2008) The seroprevalence of HIV, HBV, and HCV, among pregnant women in Tripoli Libya: are the Libyan babies at risk? AIDS - XVII International AIDS Conference: Abstract no. CDC0137.

55. Hannachi N, Hidar S, Harrabi I, Mhalla S, Marzouk M, Ghzel H, Ghannem H, Khairi H, Boukadida J (2011) Seroprevalence and risk factors of hepatitis $\mathrm{E}$ among pregnant women in central Tunisia. Pathol Biol (Paris) 59: e115-118.

56. National Travel Network and Centre $(\mathrm{NaTHNaC})$ Country information, Algeria, Tunisia and Kingdom of Morocco, 2009.

57. Benjelloun S, Bahbouhi B, Sekkat S, Bennani A, Hda N, Benslimane AA (1996) Anti-HCV seroprevalence and risk factors of hepatitis $\mathrm{C}$ virus infection in Moroccan population groups. Res Virol 147: 247-255.

58. Elasifer HA, Agnnyia YM, Al-Alagi BA, Daw MA (2010) Epidemiological manifestations of hepatitis $\mathrm{C}$ virus genotypes and its association with potential risk factors among Libyan patients. Virol J 7: 317.

59. Ben Halima M, Arrouji Z, Slim A, Ben Redjeb S (1998) Serotyping of hepatis $\mathrm{C}$ virus in Tunisia. Tunis-Medindustrie 76: 200-203.

60. Djebbi A, Triki H, Bahri O, Cheikh I, Sadraoui A, Ben Ammar A, Dellagi K (2003) Genotypes of hepatitis C virus circulating in Tunisia. Epidemiol Infect 130: 501-505.

61. Bahri O, Ezzikouri S, Alaya-Bouafif NB, Iguer F, Feydi AE, Mestiri H, Benazzouz M, Khalfallah T, Afifi R, Elkihal L, Berkane S, Marchio A, Debzi N, Dejean A, Pineau P, Triki H, Benjelloun S (2011) First multicenter study for risk factors for hepatocellular carcinoma development in North Africa. World J Hepatol 3: 24-30.

62. Alashek WA, Altagdi M (2008) Risk Factors and Genotypes of Hepatitis C Virus Infection in Libyan Patients. Libyan J Med, AOP: 080425: 162-165.

63. Khaw AJ, Salama P, Burkholder B, Dondero TJ (2000) HIV risk and prevention in emergency-affected populations: a review. Disasters 24: 181-197.

64. Krause SK, Jones RK, Purdin SJ (2000) Programmatic Responses to Refugees' Reproductive Health Needs. Int Fam Plan Perspect 26: 181-187.

65. Mavenyengwa RT, Moyo SR, Nordbø SA (2010) Streptococcus agalactiae colonization and correlation with HIV-1 and HBV seroprevalence in pregnant women from Zimbabwe. Eur J Obstet Gynecol Reprod Biol 150: 34-38.

66. Oshitani H, Kasolo FC, Mpabalwani M, Mizuta K, Luo NP, Suzuki H, Numazaki Y (1995) Hepatitis B virus infection among pregnant women in Zambia. East Afr Med J 72: 813815.

67. Ahmed SD, Cuevas LE, Brabin BJ, Kazembe P, Broadhead R, Verhoeff FH, Hart CA (1998) Seroprevalence of hepatitis $\mathrm{B}$ and $\mathrm{C}$ and HIV in Malawian pregnant women. J Infect 37: 248-251.

68. Jama H, Grillner L, Biberfeld G, Osman S, Isse A, Abdirahman M, Bygdeman S (1987) Sexually transmitted viral infections in various population groups in Mogadishu, Somalia. Genitourin Med 63: 329-332.
69. Ramos JM, Toro C, Reyes F, Amor A, Gutiérrez F (2011) Seroprevalence of HIV-1, HBV, HTLV-1 and Treponema pallidum among pregnant women in a rural hospital in Southern Ethiopia. J Clin Virol 51: 83-85.

70. Menendez C, Sanchez-Tapias JM, Kahigwa E, Mshinda H, Costa J, Vidal J, Acosta C, Lopez-Labrador X, Olmedo E, Navia M, Tanner M, Rodes J, Alonso PL (1999) Prevalence and mother-to-infant transmission of hepatitis viruses B, C, and E in Southern Tanzania. J Med Virol 58: 215-220.

71. Sinha S, Kumar M (2010) Pregnancy and chronic hepatitis B virus infection. Hepatol Res 40: 31-48.

72. Alter MJ (2007) Epidemiology of hepatitis C virus infection. World J Gastroenterol 13: 2436-2441.

73. Makuwa M, Caron M, Souquière S, Malonga-Mouelet G, Mahé A, Kazanji M (2008) Prevalence and Genetic Diversity of Hepatitis B and Delta Viruses in Pregnant Women in Gabon: Molecular Evidence that Hepatitis Delta Virus Clade 8 Originates from and Is Endemic in Central Africa. J Clin Microbiol 46: 754-756.

74. Itoua-Ngaporo A, Sapoulou MV, Ibara JR, Iloki LH, Denis F (1995) Prevalence of hepatitis B viral markers in a population of pregnant women in Brazzaville (Congo). J Gynecol Obstet Biol Reprod (Paris) 24: 534-536.

75. Kfutwah AK, Tejiokem MC, Njouom R (2012) A low proportion of $\mathrm{HBeAg}$ among $\mathrm{HBsAg}$-positive pregnant women with known HIV status could suggest low perinatal transmission of HBV in Cameroon. Virol J 9: 62.

76. Zanchetta N, Vigano P, Ferrario MP, Priuli GB, Djigbenoude O, Nardi GP, Pagano A (1990) Hepatitis B and delta hepatitis virus infection in a population of west Africa. Rev Inst Med Trop Sao Paulo 32: 36-40.

77. Candotti D, Danso K, Allain JP (2007) Maternofetal transmission of hepatitis B virus genotype E in Ghana, west Africa. J Gen Virol 88: 2686-2695.

78. Wurie IM, Wurie AT, Gevao SM (2005) Sero-prevalence of hepatitis B virus among middle to high socio-economic antenatal population in Sierra Leone. West Afr J Med 24: 1820.

79. Pirillo MF, Bassani L, Germinario EA, Mancini MG, Vyankandondera J, Okong P, Vella S, Giuliano M (2007) Seroprevalence of Hepatitis B and C Viruses Among HIVInfected Pregnant Women in Uganda and Rwanda. J. Med. Virol 79: 1797-1801.

80. Simpore J, Savadogo A, Ilboudo D, Nadambega MC, Esposito M, Yara J, Pignatelli S, Pietra V, Musumeci S (2006) Toxoplasma gondii, HCV, and HBV seroprevalence and co-infection among HIV-positive and -negative pregnant women in Burkina Faso. J Med Virol 78: 730-733.

81. MacLean B, Hess RF, Bonvillain E, Kamate J, Dao D, Cosimano A, Hoy S (2011) Seroprevalence of hepatitis B surface antigen among pregnant women attending the Hospital for Women \& Children in Koutiala, Mali. SAMJ, 102: 1 .

82. Rouet F, Chaix ML, Inwoley A, Msellati P, Viho I, Combe P, Leroy V, Dabis F, Rouzioux C; ANRS 1236 DITRAMEB\&C Study Group (2004) HBV and HCV prevalence and viraemia in HIV-positive and HIV-negative pregnant women in Abidjan, Côte d'Ivoire: the ANRS 1236 study. J Med Virol 74: $34-40$.

83. Modi AA, Feld JJ (2007) Viral hepatitis and HIV in Africa. AIDS Rev 9: 25-39. 
84. Minnie KS, van der Walt SJ, Klopper HC (2009) A systematic review of counselling for HIV testing of pregnant women. J Clin Nurs. 18: 1827-1841.

85. Njouom R, Lavoie M, Foupouapouognigni Y, Frost E, Deslandes S, Mamadou-Yaya F, Mbélesso P, Mbadingai S, Pépin J (2011) Transmission of Hepatitis C Virus Among Spouses in Cameroon and the Republic Central African . J Med Virol 83: 2113-2118.

86. Njouom R, Pasquier C, Ayouba A, Tejiokem MC, Vessiere A, Mfoupouendoun J, Tene G, Eteki N, Lobe MM, Izopet J, Nerrienet E (2005) Low risk of mother-to-child transmission of hepatitis C virus in Yaounde, Cameroon: the ANRS 1262 study. Am J Trop Med Hyg 73: 460-466.

87. Chasela CS, Wall P, Drobeniuc J, King CC, Teshale E, Hosseinipour MC, Ellington SR, Codd M, Jamieson DJ, Knight RJ, Fitzpatrick P, Kourtis AP, Hoffman IF, Kayira D, Mumba N, Kamwendo DD, Martinson F, Powderly W, van der Horst C, Kamili S (2012) BAN team. Prevalence of hepatitis $\mathrm{C}$ virus infection among human immunodeficiency virus-1-infected pregnant women in Malawi: the BAN study. J Clin Virol. 54: 318-320.

88. Madhava V, Burgess C, Drucker E (2002) Epidemiology of chronic hepatitis $\mathrm{C}$ virus infection in sub-Saharan Africa. Lancet Infect Dis 2: 293-302.

89. Laurent C, Henzel D, Mulanga-Kabeya C, Maertens G, Larouzé B, Delaporte E (2001) Seroepidemiological survey of Hepatitis $\mathrm{C}$ among commercial sex workers and pregnant women in Kinshasa, Democratic Republic of Congo. Int $\mathbf{J}$ Epidemiol 30: 872-877.

90. Ugbebor O, Aigbirior M, Osazuwa F, Enabudoso E, Zabayo $\mathrm{O}$ (2011) The prevalence of hepatitis B and C viral infections among pregnant women. North Am J Med Sci 3: 238-241.

91. Ndong-Atome GR, Makuwa M, Njouom R, Branger M, BrunVézinet F, Mahé A, Rousset D, Kazanji M (2008) Hepatitis C virus prevalence and genetic diversity among pregnant women in Gabon, central Africa. BMC Infect Dis 8: 82.

92. Okusanya BO, Aigere EO, Eigbefoh JO, Ikheloa J (2013) Seroprevalence and clinico-epidemiological correlates of hepatitis $\mathrm{C}$ viral antibodies at an antenatal booking clinic of a tertiary hospital in Nigeria. Arch Gynecol Obstet. [Epub ahead of print].

93. Collenberg E, Ouedraogo T, Ganamé J, Fickenscher H, Kynast-Wolf G, Becher H, Kouyaté B, Kräusslich HG, Sangaré L, Tebit DM (2006) Seroprevalence of Six Different Viruses Among Pregnant Women and Blood Donors in Rural and Urban Burkina Faso: A Comparative Analysis. J Med Virol 78: 683-692.

94. Khan S, Attaullah S (2011) Share of Afghanistan populace in hepatitis B and hepatitis C infection's pool: Is it worthwhile? Virol J 8: 216

95. El-Faramawy AA, El-Rashidy OF, Tawfik PH, Hussein GH (2012) Transfusion transmitted hepatitis: where do we stand now? A one center study in upper Egypt. Hepat Mon 12: 286291.

96. Mansour AK, Aly RM, Abdelrazek SY, Elghannam DM, Abdelaziz SM, Shahine DA, Elmenshawy NM, Darwish AM (2012) Prevalence of HBV and HCV infection among multitransfused Egyptian thalassemic patients. Hematol Oncol Stem Cell Ther5: 54-59.

97. Ismail AM, Ziada HN, Sheashaa HA, Shehab El-Din AB (2009) Decline of viral hepatitis prevalence among asymptomatic Egyptian blood donors: a glimmer of hope. Eur J Intern Med 20: 490-493.
98. Al-Mahroos FT, Ebrahim A (1995) Prevalence of hepatitis B, hepatitis $\mathrm{C}$ and human immune deficiency virus markers among patients with hereditary haemolytic anaemias. Ann Trop Paediatr 15: 121-128.

99. Eke AC, Eke UA, Okafor CI, Ezebialu IU, Ogbuagu C (2011) Prevalence, correlates and pattern of hepatitis B surface antigen in a low resource setting. Virol J 8: 12.

100. Rabiu KA, Akinola OI, Adewunmi AA, Omololu OM, Ojo TO (2010) Risk factors for hepatitis B virus infection among pregnant women in Lagos, Nigeria. Acta Obstetricia et Gynecologica 89: 1024-1028.

101. Mohebbi SR, Sanati A, Cheraghipour K, Rostami Nejad M, Shalmani HM, Zali MR (2011) Hepatitis C and Hepatitis B Virus Infection: Epidemiology and Risk Factors in a Large Cohort of Pregnant Women in Lorestan, West of Iran. Hepat Mon 1: 736-739.

102. Florian Bihl, Damiano Castelli, Francesco Marincola, Roger Y Dodd, Christian Brander (2007) Transfusion-transmitted infections. J Transl Med 5: 25.

103. Kamal SM (2008) Acute Hepatitis C: A Systematic Review. Am J Gastroenterol 103: 1283-1297.

104. Kumar A, Sharma KA, Gupta RK, Kar P, Chakravarti A (2007) Prevalence \& risk factors for hepatitis C virus among pregnant women. Indian J Med Res 126: 211-215.

105. Moore A, Herrera G, Nyamongo J, Lackritz E, Granade T, Nahlen B, Oloo A, Opondo G, Muga R, Janssen R (2001) Estimated risk of HIV transmission blood transfusion in Kenya. Lancet 358: 657-60.

106. Saleh DA, Shebl FM, El-Kamary SS, Magder LS, Allam A, Abdel-Hamid M, Mikhail N, Hashem M, Sharaf S, Stoszek SK, Strickland GT (2010) Incidence and risk factors for community-acquired hepatitis $\mathrm{C}$ infection from birth to 5 years of age in rural Egyptian children. Trans R Soc Trop Med Hyg 104: 357-363.

107. Candotti D, Sarkodie F, Allain JP (2001) Residual risk of transfusion in Ghana. Br J Haematol 113: 37-39

108. Terrault NA, Dodge JL, Murphy EL, Tavis JE, Kiss A, Levin TR, Gish RG, Busch MP, Reingold AL, Alter MJ (2013) Sexual transmission of hepatitis $\mathrm{C}$ virus among monogamous heterosexual couples: The HCV partners study. Hepatology 57: 881-889.

109. Duru MU, Aluyi HS, Anukam KC (2009) Rapid screening for co-infection of HIV and HCV in pregnant women in Benin City, Edo State, Nigeria. Afr Health Sci 9: 137-142.

110. Mohamed MK, Abdel-Hamid M, Mikhail NN, Abdel-Aziz F, Medhat A, Magder LS, Fix AD, Strickland GT (2005) Intrafamilial transmission of hepatitis $\mathrm{C}$ in Egypt. Hepatology 42: 683-637.

111. Caudai C, Battiata M, Riccardi MP, Toti M, Bonazza P, Padula MG, Pianese M, Valensin PE (2003) Vertical Transmission of the Hepatitis C Virus to Infants of AntiHuman Immunodeficiency Virus-Negative Mothers: Molecular Evolution of Hypervariable Region 1 in Prenatal and Perinatal or Postnatal Infections. J Clin Microbiol 41: 3955-3959.

112. Ogunro PS, Adekanle DA, Fadero FF, Ogungbamigbe TO, Oninla SO (2007) Prevalence of anti-hepatitis C virus antibodies in pregnant women and their offspring in a tertiary hospital in Southwestern Nigeria. J Infect Developing Countries 1: 333-336.

113. Olokoba AB, Accama LA, Gashau W, Salawu FK (2011) Risk factors and clinical presentation of hepatitis $\mathrm{C}$ virus 
infection in Nigerians with chronic liver disease. Trop Doct 41: 146-147.

114. Adoga MP, Pennap G, Akande BO, Mairiga JP, Pechulano S, Agwale SM (2010) Evaluation of a recombinant DNA hepatitis $\mathrm{B}$ vaccine in a vaccinated Nigerian population. $\mathrm{J}$ Infect Dev Ctries 4: 740-744.

115. Liang X, Bi S, Yang W, Wang L, Cui G, Cui F, Zhang Y, Liu J, Gong X, Chen Y, Wang F, Zheng H, Wang F, Guo J, Jia Z, Ma J, Wang H, Luo H, Li L, Jin S, Hadler SC, Wang Y (2009) Epidemiological serosurvey of hepatitis B in China Declining HBV prevalence due to hepatitis B vaccination. Vaccine 27: 6550-6557.

116. Weinbaum CM, Williams I, Mast EE, Wang SA, Finelli L, Wasley A, Neitzel SM, Ward JW; Centers for Disease Control and Prevention (CDC) (2008) Recommendations for identification and public health management of persons with chronic hepatitis B virus infection. MMWR 57: 1-20.

117. Shuler CM, Fiore AE, Neeman R, Bell BP, Kuhnert W, Watkins S, Kilgour K, Arnold KE (2009) Reduction in hepatitis B virus Seroprevalence among U.S.-born children of foreign-born Asian parents - benefit of universal infant hepatitis B vaccination. Vaccine 27: 5942-5947.

118. Hasegawa I, Tanaka Y, Kurbanov F, Yoshihara N, El-Gohary A, Lyamuya E, Matee M, Magessa P, Fujiwara K, Ozasa A, Sugauchi F, Orito E, Ueda R, Mizokami M (2006) Molecular epidemiology of hepatitis B virus in the United Republic of Tanzania. J Med. Virol 78: 1035-1042.

119. Mwangi J, Nganga Z, Songok E, Kinyua J, Lagat N, Muriuki J, Lihana R, Khamadi S, Osman S, Lwembe R, Kiptoo M, Mwau M, Chirchir R, Mpoke S, Nyamongo J, Okoth F, Yamada R, Kageyama S, Ichimura H (2008) Molecular genetic diversity of hepatitis B virus in Kenya. Intervirology 51: 417-421.

120. Yang J, Xing K, Deng R, Wang J, Wang X (2006) Identification of Hepatitis $\mathrm{B}$ virus putative inter-genotype recombinants by using fragment typing. J Gen Virol 87 : 2203-2215.

121. Hübschen JM, Mugabo J, Peltier CA, Karasi JC, Sausy A, Kirpach P, Arendt V, Muller CP (2009) Exceptional genetic variability of hepatitis $B$ virus indicates that Rwanda is east of an emerging African genotype E/A1 divide. J Med Virol 81: 435-440.

122. Andernach IE, Hübschen JM, Muller CP (2009) Hepatitis B virus: the genotype E puzzle. Rev Med Virol 19: 231-240.

123. Pena-López MJ, Suárez-Bordón P, García-Bardeci D, Rodríguez-San Román JL, Pérez-González MC, LafargaCapuz B (2005) Hepatitis B virus genotypes in chronic carriers on the island of Gran Canaria. Clinical and epidemiological characteristics. Enferm Infecc Microbiol Clin 23: $415-418$
124. Zhao L, Feng Y, Xia XS (2012) The different epidemic and evolution of HCV genotypes. Yi Chuan 34: 666-672.

125. Bassit L, Ribeiro-Dos-Santos G, Da Silva LC, Takei K, Villaça P, David-Neto E, Chamone D, Sáez-Alquézar A (1999) Genotype Distribution of Hepatitis C Virus in Satildeo Paulo, Brazil: Rare Subtype Found. Hepatology 29: 994-995.

126. Rapicetta M, Argentini C, Dettori S, Spada E, Pellizzer G, Gandin C (1998) Molecular heterogeneity and new subtypes of HCV genotype 4. Res Virol 149: 293-297.

127. Muasya T, Lore W, Yano K, Yatsuhashi H, Owiti FR, Fukuda M, Tamada MY, Kulundu J, Tukei J, Okoth FA (2008) Prevalence of hepatitis $\mathrm{C}$ virus and its genotypes among a cohort of drug users in Kenya. East Afr Med J 85: 318-325.

128. Stuyver L, Rossau R, Wyseur A, Duhamel M, Vanderborght B, Van Heuverswyn H, Maertens G (1993) Typing of hepatitis $\mathrm{C}$ virus isolates and characterization of new subtypes using a line probe assay. J Gen Virol 74:1093-1102.

129. Kamal SM (2006) Genotypic Variations Around the World:Is Hepatitis C Virus Evolving? Curr Hepat Rep 5: 142-149.

130. Abreha T, Woldeamanuel Y, Pietsch C, Maier M, Asrat D, Abebe A, Hailegiorgis B, Aseffa A, Liebert UG (2011) Genotypes and viral load of hepatitis $\mathrm{C}$ virus among persons attending a voluntary counseling and testing center in Ethiopia. J Med Virol 83: 776-82.

131. Abid K, Quadri R, Veuthey AL, Hadengue A, Negro F (2000) A novel hepatitis $\mathrm{C}$ virus (HCV) subtype from Somalia and its classification into HCV clade 3. J Gen Virol 81: 14851493.

132. Razafindratsimandresy R, Dubot A, Ramarokoto CE, Iehlé C, Soares JL, Rousset D (2007) Hepatitis C virus infection and genotypes in Antananarivo, Madagascar. J Med Virol 79: 1082-1088.

133. Rodrigues Mda C, Viotti JB, Braga RF, Lourenço LF, Antunes CM, Lambertucci JR (2008) HIV/HCV coinfection in Infectious Disease Units in Mozambique and Brazil: a comparative study. Rev Soc Bras Med Trop 41: 518.

\section{Corresponding author}

Ishag Adam

Faculty of Medicine,

Khartoum University, Sudan

PO Box 102

Khartoum, Sudan

Telephone: +249912168988

Fax: +249183771211

Email: ishagadam@hotmail.com

Conflict of interests: No conflict of interests is declared. 